\title{
Bio-mineralogy of Selected Skin Cancers
}

\section{Maciej Pawlikowski* and Magdalena Miler}

Bio-mineralogy Lab, University of Science and Technology, Poland

\begin{abstract}
Investigation of Carcinoma basocellulare solidum exulcerans, Carcinoma basocellulare superficiale multicentricum, and Trichoepithelioma was performed using histology and bio-mineralogical methods. Obtained data confirmed elevated levels of some elements in altered skin tissues. Moreover, rare micrograins of phosphates were observed. Additionally, examination of bio mineralization of human tissues suggests that higher local mineralization (of tissue fluids) may lead to mistakes in DNA code at the moment of cell division. It is possible that cancer tissues are secondarily mineralized by activity of cancer cells. Further research is needed to answer questions that arose.
\end{abstract}

Keywords: Bio-mineralogy, Skin cancers

\section{Introduction}

Number of people diagnosed with cancer, in particular different types of skin cancer, is steadily increasing [1-6]. Skin cancer is one of the forms of cancer that often ends in death. It is therefore important both to prevent this group of cancers and to develop effective treatment.

Development of research techniques allows us to discover new areas of knowledge. This also applies to research in oncology, including skin cancers [1-9].

This work presents such new research directions in the study of skin cancer, including scanning polarization microscopy. Examinations described herein were preceded by histological identification of the samples.

The aim of the study was bio-mineralogical diagnosis of mineralization in neoplastic skin tissue. By bio-mineralization we understand not only the occurrence of mineral grains or crystals, i.e., so called overt mineralization [1-5], but also the presence of hidden mineralization [10-13]. Hidden mineralization affects tissues and body fluids without manifesting in the aforementioned forms, and it consists of substituting elements for atomic structures of organic compounds. It mostly affects areas with tissue changes. This type of mineralization is impossible to detect in its early stages using methods other than chemical. It is sensitive chemical methods that reveal too high or too low content of elements in the tissues, which indicate that the tissue environment deviates from normal conditions [1]. Apart from the "mineral" factors, there are others, for instance different types of radiation [14,15]. Mineral, and in fact chemical "abnormality" of the environment is particularly important at the time of cell division, i.e., cell multiplication.

When cell division takes place in "abnormal" environment with excessive or insufficient "mineralization", there is a risk of an error occurring in the section of DNA responsible for the rate of cell procreation [16].

Such errors in that particular DNA section may be numerous and varied. In consequence, the cell multiplies more often than it would with the original genetic code. This defect leads to rapid growth of large number of cells and formation of tumors. The diversity of mineral (and organic) substances, and the fact that cell proliferation is directed not by one place in DNA, but its whole section, result in a huge variety of tumors both in skin and other organs and tissues.

\section{Materials and Methods}

Due to the availability of the samples, this work focuses on skin tumors-Carcinoma basocellulare solidum exulcerans, Carcinoma basocellulare superficiale multicentricum. The authors are grateful to doctors Krzysztof Czajecki, MD, and Stanisław Bajcar, MD, for providing study material.

Four tumors diagnosed as Carcinoma basocellulare and two cases of Trichoepithelioma tumors were obtained from the Department of Pathomorphology of the Provincial Hospital No. 2 in Rzeszow. Assessment of histological preparations was performed at the Department of Pathomorphology of the Regional Hospital No. 2 in Rzeszow and at the Department of Pathomorphology of Collegium Medicum at the Jagiellonian University in Cracow. Preparations for scanning microscopy were dewaxed in the Department of Pathomorphology of the 5th Military Clinical Hospital with Polyclinic in Cracow. Analyzed samples are presented in Table 1.

Observations of preparations under a polarizing microscope were made at the Department of Mineralogy, Petrography and Geochemistry of the AGH University of Science and Technology in Cracow, and were documented with micrographs. Tests using scanning microscope combined with EDS chemical analyzer were performed at the Jagiellonian University and the AGH University of Science and Technology in Cracow. Part of the results was used by M.Sc Engineer. Magdalena Miler in her thesis entitled "Bio-mineralogical studies of mineralization in selected skin lesions", under the thesis advisement of Prof. Maciej Pawlikowski.

\section{Results}

Over a dozen samples were examined, but due to repetitive observations and results, only selected ones are presented here. Table 1 shows the result of chemical microanalysis performed at measurement point 1 . The content of tested elements is given in weight percentages. It

*Corresponding author: Maciej Pawlikowski, Bio-mineralogy Lab, University of Science and Technology, Poland, Tel: +12617 5232; E-mail: mpawlik@agh.edu.pl

Received July 24, 2017; Accepted October 13, 2017; Published October 18, 2017

Citation: Pawlikowski M, Miler M (2017) Bio-mineralogy of Selected Skin Cancers. J Carcinogene Mutagene 8: 307. doi: 10.4172/2157-2518.1000307

Copyright: @ 2017 Pawlikowski M, et al. This is an open-access article distributed under the terms of the Creative Commons Attribution License, which permits unrestricted use, distribution, and reproduction in any medium, provided the original author and source are credited. 
is a mineralized area, as evidenced by calcium and other elements levels, which are elevated in comparison to non-mineralized tissue (Table 1, Figure 1). Table 2 shows chemical analysis of "clean" tissue - not affected by the mineralization process (measurement point 2). In this spot there are no elevated levels of elements that could be relevant to tissue mineralization (e.g. calcium, phosphorus). Slightly elevated contents of sodium, magnesium and aluminum probably come from glass and are a result of calculation error. In measurement point 3 , chemical analysis of mineralized area was performed. In that area (Figure 2) tiny, gleaming concentrations of minerals are visible. Chemical analysis (Table 3 , Figure 3) shows elevated levels of calcium and sulphur in comparison with "clean" tissue. Table 4 shows the result of chemical microanalysis performed at measurement point 4 . The contents of tested elements are given in weight percentages. It is a mineralized area, as evidenced by calcium and sulphur levels, which are elevated in comparison to nonmineralized tissue. Table 5 shows the result of chemical analysis of the

\begin{tabular}{|c|c|c|c|c|}
\hline Histological diagnosis & Preparation number & Patient's gender and age & Size of the lesion & Notes \\
\hline \multirow{3}{*}{ Carcinoma basocellulare solidum } & 256442 & Woman, age 61 & $6 \times 4 \mathrm{~mm}$ & -follicular differentiation in places \\
\hline & & & & -necrotic fields present \\
\hline & & & & -no major calcifications \\
\hline Carcinoma basocellulare solidum exulcerans & 259814 & Woman, age 41 & $7 \times 8 \mathrm{~mm}$ & -no major calcifications \\
\hline $\begin{array}{l}\text { Carcinoma basocellulare Superficiale } \\
\text { multicentricum }\end{array}$ & 255976 & Woman, age 48 & $4 \mathrm{~mm}$ diameter & $\begin{array}{l}\text {-surface covered by scab } \\
\text {-no large calcifications }\end{array}$ \\
\hline \multirow{4}{*}{ Trichoepithelioma } & 255750 & Woman age 66 & $12 \times 7 \mathrm{~mm}$ & -clear follicular differentiation \\
\hline & & & & -visible areas of calcification \\
\hline & & Woman, age 54 & $17 \times 7 \times 4 \mathrm{~mm}$ & -visible areas of parakeratosis \\
\hline & 260149 & & & -small concentrations of calcification present \\
\hline
\end{tabular}

Table 1: Data concerning origin and character of samples.

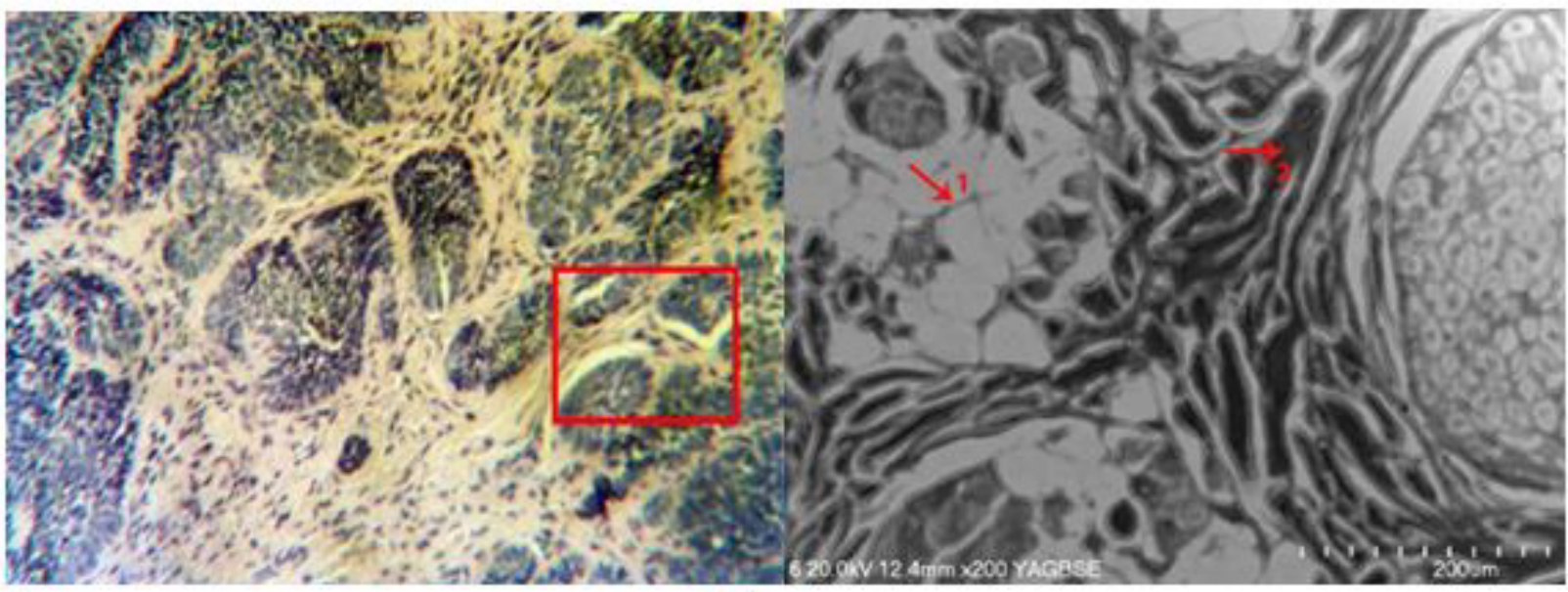

A

B

Figure 1: A-Carcinoma basocellulare solidum. Visible well-defined nodes of cancer cells with palisading pattern around the circumference. The preparation is stained with hematoxylin and eosin. Polarizing microscope partially $1 \mathrm{~N}$, magnification $60 \mathrm{X}$. B-Carcinoma basocellulare solidum. Scanning microscope, magnification $200 \mathrm{X}$. In point 1 , analysis of the tissue affected by mineralization process was performed. In point 2 , analysis of non-mineralized tissue was performed.

\begin{tabular}{|c|c|}
\hline element & Content (weight\%) \\
\hline $\mathrm{Na}$ & 0.73 \\
\hline $\mathrm{Mg}$ & 0.49 \\
\hline $\mathrm{Al}$ & 0.12 \\
\hline $\mathrm{Si}$ & 2.17 \\
\hline $\mathrm{Ca}$ & 1.61 \\
\hline $\mathrm{Fe}$ & 0 \\
\hline $\mathrm{Sn}$ & 0 \\
\hline $\mathrm{P}$ & 0 \\
\hline $\mathrm{S}$ & 1.23 \\
\hline $\mathrm{K}$ & 0.5 \\
\hline $\mathrm{Cl}$ & 1.45 \\
\hline $\mathrm{N}$ & 0 \\
\hline
\end{tabular}

Table 2: Results of chemical analysis of sample in point 1.

\begin{tabular}{|c|c|}
\hline element & Content (weight\%) \\
\hline $\mathrm{Na}$ & 0 \\
\hline $\mathrm{Mg}$ & 0 \\
\hline $\mathrm{Al}$ & 0.1 \\
\hline $\mathrm{Si}$ & 0 \\
\hline $\mathrm{Ca}$ & 0.29 \\
\hline $\mathrm{Fe}$ & 0 \\
\hline $\mathrm{Sn}$ & 0 \\
\hline $\mathrm{S}$ & 0 \\
\hline $\mathrm{K}$ & 0.16 \\
\hline $\mathrm{Cl}$ & 0 \\
\hline $\mathrm{N}$ & 0 \\
\hline
\end{tabular}

Table 3: Results of chemical analysis of sample in point 2. 


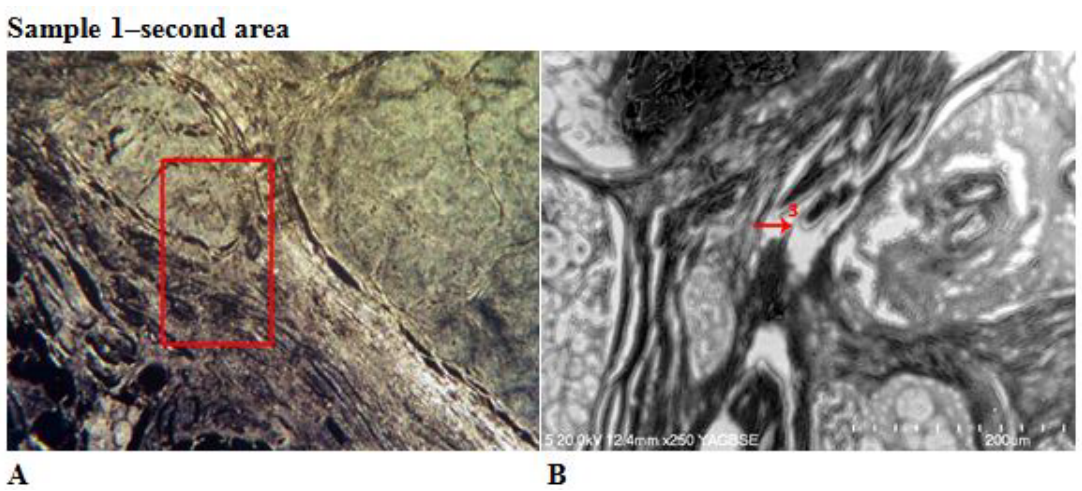

Figure 2: A-Carcinoma basocellulare solidum preparation. Polarizing microscope $\mathrm{XN}$, magnification $60 \mathrm{X}$. Visible tiny, gleaming concentrations of minerals near the elongated shape. Marked area is shown in photo 3B. B-Carcinoma basocellulare solidum preparation. Scanning microscope, magnification $250 \mathrm{X}$. In point 3 , chemical analysis of tissue affected by mineralization was performed.

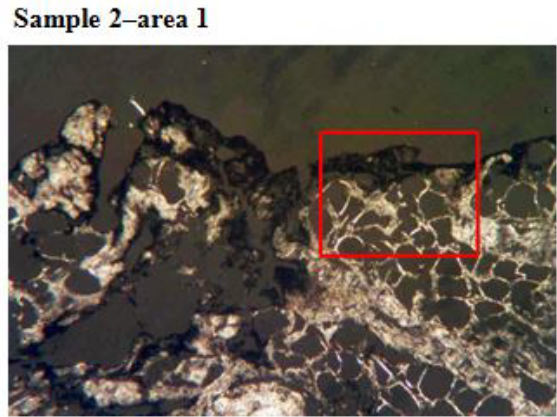

A

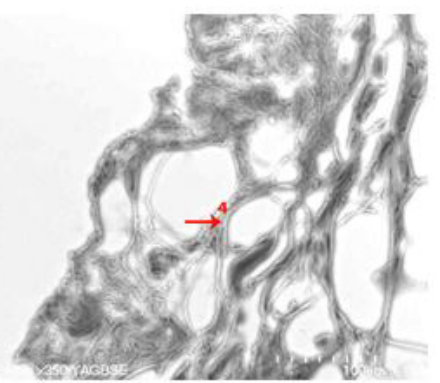

B

Figure 3: A-Carcinoma basocellulare solidum. Polarizing microscope, polarizators partially X, magnification 60X. Visible mineralization in the form of tiny, gleaming concentrations of minerals around cells. B-Carcinoma basocellulare solidum. Scanning microscope, magnification $350 \mathrm{X}$. In point 4 , chemical analysis was performed in mineralized areas visible in $4 \mathrm{~A}$.

\begin{tabular}{|c|c|}
\hline element & Content (weight\%) \\
\hline $\mathrm{Na}$ & 0 \\
\hline $\mathrm{Mg}$ & 0 \\
\hline $\mathrm{Al}$. & 0,1 \\
\hline $\mathrm{Si}$ & 0 \\
\hline $\mathrm{Ca}$ & 6,29 \\
\hline $\mathrm{Fe}$ & 0 \\
\hline $\mathrm{Sn}$ & 0 \\
\hline $\mathrm{P}$ & 0 \\
\hline $\mathrm{S}$ & 1,16 \\
\hline $\mathrm{K}$ & 0 \\
\hline $\mathrm{Cl}$ & 0 \\
\hline $\mathrm{N}$ & 0 \\
\hline
\end{tabular}

Table 4: Results of chemical analysis of sample 1-area 2, point 3.

mineralized area at measuring point 5 (Figure 4). The analysis shows slightly increased levels of sodium, magnesium, silicon, and potassium. Measurement point 6 was located in the mineralized area visible in Figure 5 as a brighter, elongated shape. Chemical analysis presented in Table 5 shows elevated levels of calcium, sulphur, potassium, and iron in point 6 . Table 6 shows chemical analysis of the outer part of mineralized area visible in Figure 6 in the form of a spherical shape. Measurement point 7 contained elevated levels of calcium, sulfur, and trace amounts of potassium in comparison to healthy, non-cancerous tissue.

\begin{tabular}{|c|c|}
\hline element & Content (weight\%) \\
\hline $\mathrm{Na}$ & 0 \\
\hline $\mathrm{Mg}$ & 0 \\
\hline $\mathrm{Al}$ & 0 \\
\hline $\mathrm{Si}$ & 0 \\
\hline $\mathrm{Ca}$ & 3,12 \\
\hline $\mathrm{Fe}$ & 0 \\
\hline $\mathrm{Sn}$ & 0 \\
\hline $\mathrm{P}$ & 0 \\
\hline $\mathrm{S}$ & 1,18 \\
\hline $\mathrm{K}$ & 0 \\
\hline $\mathrm{Cl}$ & 0 \\
\hline $\mathrm{N}$ & 0 \\
\hline
\end{tabular}

Table 5: Results of chemical analysis of sample 2-area 1, point 4.

Table 7 shows chemical analysis of the inner part of mineralized area visible in Figure 6, measurement point 8 . The analysis showed elevated level of calcium; it was significantly higher than in the outer part of the mineralized area (measurement point 7). Apart from calcium, slightly elevated levels of phosphorus, sulfur, and potassium were found. Table 8 shows chemical analysis of the spindle-shaped mineral concentration visible in Figure 7. Analysis of measurement point 13 showed elevated level of calcium and slightly elevated level of aluminum. Table 9 summarizes the results of element content analysis from point 14 . Compared to point 13 , there is a noticeable increase in 


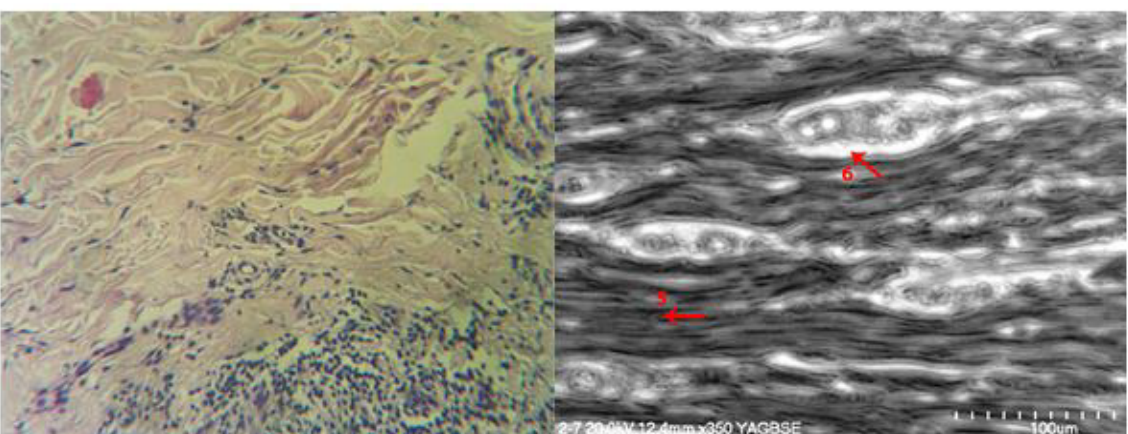

A

Figure 4: A-Carcinoma basocellulare solidum. On the periphery of solid basal cell carcinoma, single nodes of tumor cells are located within the inflammatory mass adjacent to the small vessels. Preparation stained with hematoxylin and eosin. Polarizing microscope $1 \mathrm{~N}$, magnification $60 \mathrm{X}$. B-Carcinoma basocellulare solidum. In points 5 and 6 mineralized tissue analysis was performed. Scanning microscope, magnification $350 \mathrm{X}$.

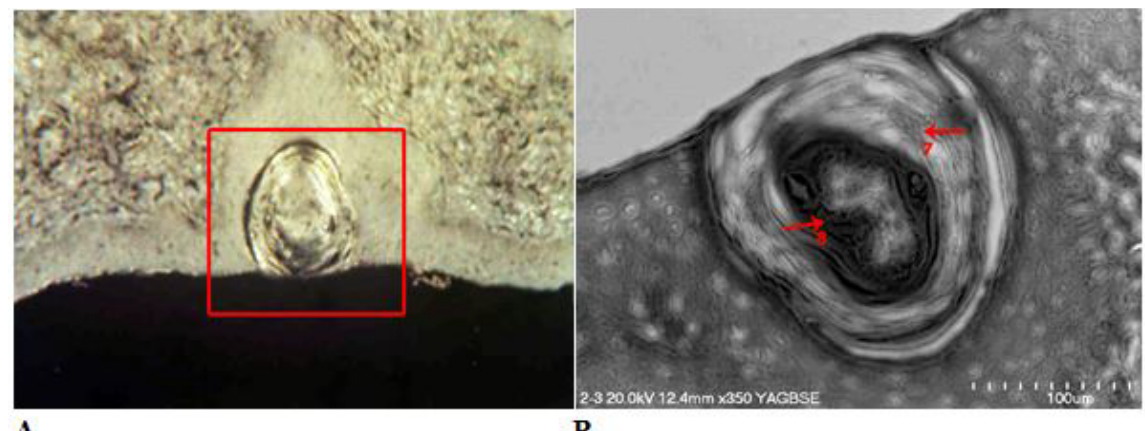

Figure 5: A-Carcinoma basocellulare solidum. Polarizing microscope $\mathrm{X} \mathrm{N}$, magnification $60 \mathrm{X}$. Visible spherical form of mineralization. B-SEM. Enlarged area marked in Figure 6A, with indicated spots where chemical analyses were performed (EDS).

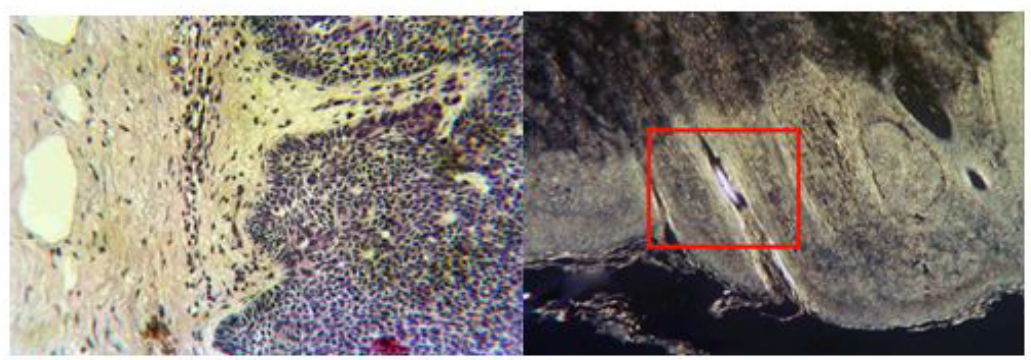

A

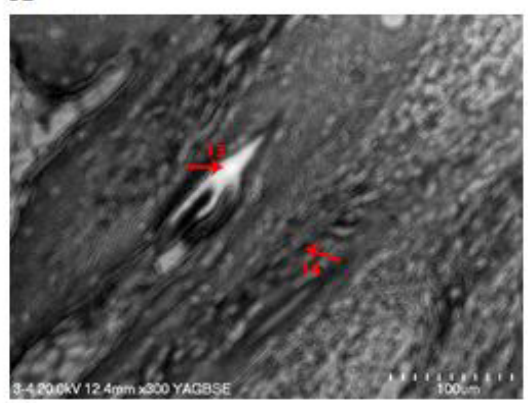

C

B

Figure 6: A-Carcinoma basocellulare solidum. Visible border of tumor penetrating into dermis, with a characteristic palisading pattern of cells on the periphery. Preparation stained with hematoxylin and eosin. Polarizing microscope $1 \mathrm{~N}$, magnification $60 \mathrm{X}$. B-Carcinoma basocellulare solidum exulcerans. Polarizing microscope $\mathrm{XN}$, magnification $60 \mathrm{X}$. Visible spindle-shaped concentration of minerals. Marked area is show in Photo 18. C-Carcinoma basocellulare solidum exulcerans. SEM magnification 300X. Mineralized area analysis was performed in point 13. "Clean" tissue analysis was performed in point 14. 


\begin{tabular}{|c|c|}
\hline element & Content (weight\%) \\
\hline $\mathrm{Na}$ & 0,21 \\
\hline $\mathrm{Mg}$ & 0,27 \\
\hline $\mathrm{Al}$. & 0 \\
\hline $\mathrm{Si}$ & 0,26 \\
\hline $\mathrm{Ca}$ & 1,31 \\
\hline $\mathrm{Fe}$ & 0,1 \\
\hline $\mathrm{Sn}$ & 0 \\
\hline $\mathrm{P}$ & 3,44 \\
\hline $\mathrm{S}$ & 4,54 \\
\hline $\mathrm{K}$ & 0,3 \\
\hline $\mathrm{Cl}$ & 0 \\
\hline $\mathrm{N}$ & 0 \\
\hline
\end{tabular}

Table 6: Results of chemical analysis of sample in point 5.

\begin{tabular}{|c|c|}
\hline element & Content (weight\%) \\
\hline $\mathrm{Na}$ & 0 \\
\hline $\mathrm{Mg}$ & 0 \\
\hline $\mathrm{Al}$. & 0 \\
\hline $\mathrm{Si}$ & 0 \\
\hline $\mathrm{Ca}$ & 1,18 \\
\hline $\mathrm{Fe}$ & 0 \\
\hline $\mathrm{Sn}$ & 0 \\
\hline $\mathrm{P}$ & 0 \\
\hline $\mathrm{S}$ & 2,35 \\
\hline $\mathrm{K}$ & 0,08 \\
\hline $\mathrm{Cl}$ & 0 \\
\hline $\mathrm{N}$ & 0 \\
\hline
\end{tabular}

Table 7: Results of chemical analysis of sample 2, point 7.

\begin{tabular}{|c|c|}
\hline element & Content (weight\%) \\
\hline $\mathrm{Na}$ & 0 \\
\hline $\mathrm{Mg}$ & 0 \\
\hline $\mathrm{Al}$. & 0 \\
\hline $\mathrm{Si}$ & 1,1 \\
\hline $\mathrm{Ca}$ & 14,42 \\
\hline $\mathrm{Fe}$ & 0 \\
\hline $\mathrm{Sn}$ & 0 \\
\hline $\mathrm{P}$ & 2,2 \\
\hline $\mathrm{S}$ & 0 \\
\hline $\mathrm{K}$ & 0,51 \\
\hline $\mathrm{Cl}$ & 0 \\
\hline $\mathrm{N}$ & 0 \\
\hline
\end{tabular}

Table 8: Results of chemical analysis of sample 2, point 8. the level of calcium, sulfur, and phosphorus in the tissue. EDS chemical analysis performed in the spaces between mineral grains (Figure 8, Table 10) shows that also in those places levels of calcium, sodium, phosphorus, sulphur and iron are elevated.

\section{Discussion}

Two types of skin cancer-Carcinoma basocellulare and Trichoepithelioma-have been studied in order to examine the phenomenon of mineralization in these cancers.

Bio-microscopic studies allowed for performing histopathological characteristics and pre-assessment of mineralization. A more accurate qualification of the occurrence of mineral deposits in examined preparations, as well as examination of the form of mineralization, was possible under a polarizing microscope with a chemical analysis attachment (EDS).

Based on obtained results, it can be concluded that mineralization of the examined skin cancers has both hidden and overt nature.

Hidden mineralization means presence of elevated levels of certain elements (especially calcium and in some cases phosphorus) in the test tissues.

This form of mineralization doesn't manifest as mineral grains or microcrystals. This means that the elements present in increased quantities are incorporated into the biological structures of the tissuebuilding compounds. Previous studies [17-19] have shown that insertions of these elements occur at sites of structural defects in tissues. By integrating into biological structures in this way, these elements change their nature and physicochemical properties, and thus their functions. Hidden mineralization was found in samples of Carcinoma basocellulare solidum and Trichoepithelioma.

Over time, hidden mineralization may, but does not have to transform into overt mineralization, which was also found in examined tumors [20-23].

Overt mineralization means presence of very fine mineral grains within the tissues, in this case neoplastic tissues. This type of mineralization was found in all tested preparations.

Overt mineralization occurs in examined preparations in the following forms:

-Tiny concentrations of minerals visible through tissue

-Thin, mineralized margins around cells

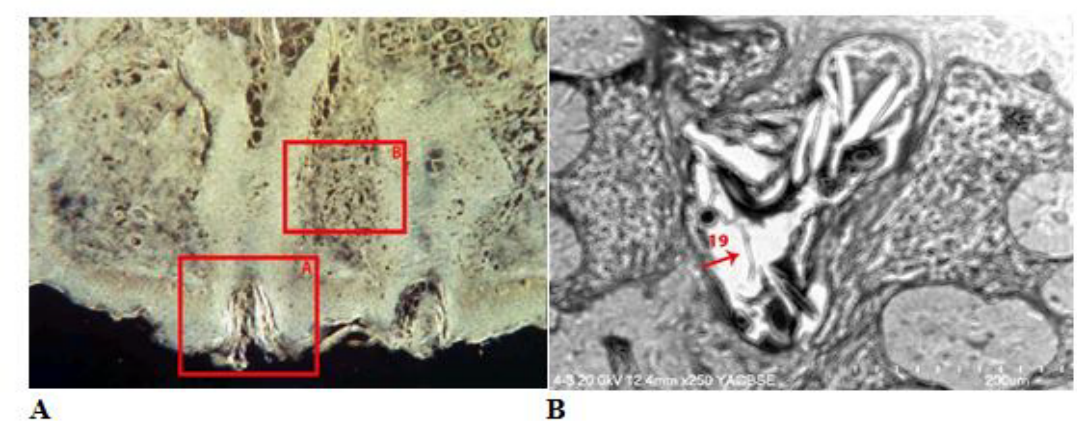

Figure 7: A-Trichoepithelioma. Image of altered tissue structures captured with polarizing microscope. Visible mineralization in the form of elongated clusters in the marginal part of the specimen (area A) and in the form of very fine mineral clusters around cells (area B). Polarizing microscope, XN, magnification 60 X. B-SEM. Visible tiny opaque mineral clusters. Point 9-site of EDS chemical analysis. 


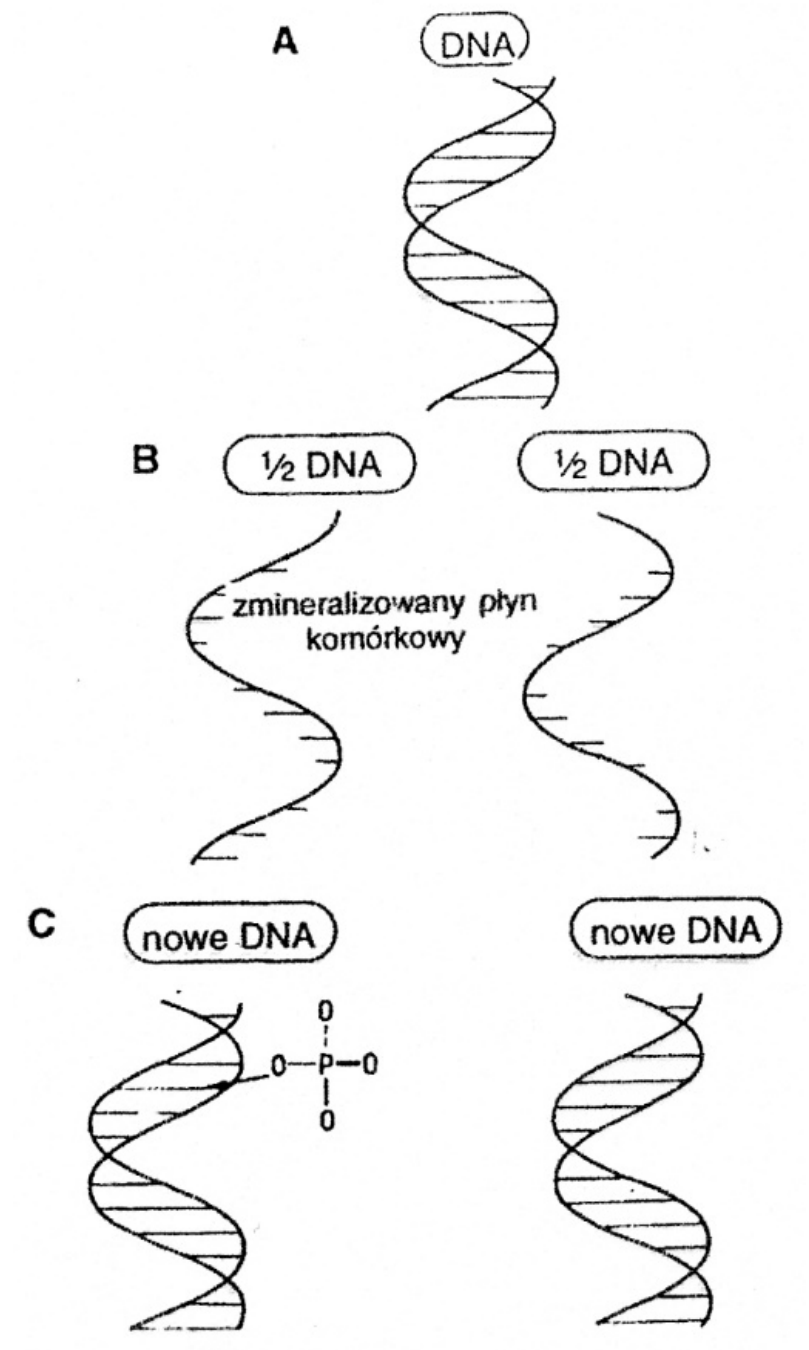

Figure 8: Hypothetical DNA deformation in the segment responsible for multiplication during cell division in environment over-mineralized with PO43. A-Preliminary DNA splitting phase. B-Division of DNA into two parts in cellular fluid with elevated ionic content of e.g. PO43. Ion incorporation into DNA section responsible for regulating cell procreation. C-Two new DNA spirals created during cell division. Left spiral, deformed by ion (or compound) incorporation goes into a state of permanent multiplication, leading to proliferation of cells and the formation of tumor.

\section{-Characteristic spherical forms}

-Elongated, very fine mineral grains

-Irregular mineral deposits. In tissues affected by mineralization, content of calcium and, sometimes, phosphorus is elevated in comparison to "clean"-non-mineralized-tissue.

In most of the spots where chemical microanalysis of mineralized areas has been performed, increased levels of calcium have been found, often in the absence of phosphorus. Only one of the measuring points showed presence of phosphorus in the absence of calcium. Three points contained increased levels of both calcium and phosphorus.

Increased silicon content recorded in some cases is most likely due to a calculation error, but it cannot be determined without a doubt whether it has a pathological basis.

Previous studies on the mineralization of tumors indicate that this type of mineralization mainly consists of calcium phosphate, sometimes accompanied by sulfur, iron, silicon, magnesium, sodium, chlorine, and aluminum. It should be remembered that EDS method has the sensitivity to allow precise determination of elements with an accuracy of $0.0 \mathrm{X} \%$. This means that it is very likely that described elements are accompanied by others that are present in tissues in quantities smaller than $0.0 \mathrm{X} \%$.

One of the main questions resulting from presented research is:

1. Do cancerous tissues tend to concentrate certain elements?

or:

2. Does "elevated mineralization" in tissue, e.g. in body fluids, occur first, and its consequence is cancer?

Re. 1 In case of a developed tumor (e.g. skin tumor), the answer to the first question is less important from the viewpoint of the genesis of cancer. Here the question is how to get rid of the mineralization if it affects procreation of cells.

Re. 2 This question is fundamental from the viewpoint of the genesis of the mechanism of cell neoplasia.

It is highly likely that both hidden tissue mineralization and overt mineralization, including so-called calcifications, may favor structural defects of DNA generated during the chromosome division in the process of cell multiplication. The division environment in a cell with abnormal content of elements or compounds (too low or too high mineralization) may favor deformations of the DNA segment that is

\begin{tabular}{|c|c|}
\hline element & Content (weight\%) \\
\hline $\mathrm{Na}$ & 0 \\
\hline $\mathrm{Mg}$ & 0 \\
\hline $\mathrm{Al}$. & 0,06 \\
\hline $\mathrm{Si}$ & 0 \\
\hline $\mathrm{Ca}$ & 0,09 \\
\hline $\mathrm{Fe}$ & 0 \\
\hline $\mathrm{Sn}$ & 0 \\
\hline $\mathrm{P}$ & 0 \\
\hline $\mathrm{S}$ & 0,04 \\
\hline $\mathrm{Kl}$ & 0 \\
\hline $\mathrm{N}$ & 0 \\
\hline
\end{tabular}

Table 9: Results of chemical analysis of sample, point 13.

\begin{tabular}{|c|c|}
\hline element & Content (weight\%) \\
\hline $\mathrm{Na}$ & 0 \\
\hline $\mathrm{Mg}$ & 0 \\
\hline $\mathrm{Al}$ & 0 \\
\hline $\mathrm{Si}$ & 0 \\
\hline $\mathrm{Ca}$ & 4,97 \\
\hline $\mathrm{Fe}$ & 0 \\
\hline $\mathrm{Sn}$ & 0 \\
\hline $\mathrm{P}$ & 1,12 \\
\hline $\mathrm{S}$ & 2,42 \\
\hline $\mathrm{K}$ & 0 \\
\hline $\mathrm{Cl}$ & 0 \\
\hline $\mathrm{N}$ & 0 \\
\hline
\end{tabular}

Table 10: Results of chemical analysis of sample, point 14 . 
responsible for the rate of mitotic division. Thus, mineralization of tissues and body fluids (caused by both external and internal factors) may promote tumor formation.

\section{References}

1. Bunyaviroch T, Coleman RE (2006) PET evaluation of lung cancer. J Nucl Med 47: 451-469.

2. Boyle P, Doré JF, Autier P, Ringborg U (2004) Cancer of the skin: a forgotten problem in Europe. Ann Onkol 15: 5-6.

3. ChichełA, Skowronek J (2005) Współczesne leczenie raka skóry-dermatologia, chirurgia czy radioterapia? Współczesna Onkol 10: 429-435.

4. Daniel L, Leśniewski K (2005) Leczenie długotrwale rozwijającego sięraka podstawnokomórkowego skóry, niszczącego połowętwarzy-opis przypadku. Współczesna Onkol 10: 440 -442.

5. Deja M, Teresiak E, Buczyńska, Karaś A, Jenerowicz D, et al. (2004) Analiza częstości występowania poszczególnych typów histologicznych raka podstawnokomórkowego skóry, umiejscowienia zmian oraz wieku i płci pacjentów. Postępy Dermatol Alergol 5: 231-239.

6. Devereux TR (1996) Molecular mechanisms of lung cancer. Interaction of environmental and genetic factors. Chest 5: 14S-19S

7. Harper J, Moses MA (2006) Molecular regulation of tumor angiogenesis: mechanisms and therapeutic implications. EXS 96: 223-268.

8. Juszko-Piekut M, Kołosza Z, Moździerz A (2004) The influence of selected environmental factors on lung cancer incidence in immigrant population of industrial areas. Polish J Environ Stu 13: 174-180.

9. Kokot F (1993) Gospodarka wodno-elektrolitowa i kwasowo-zasadowa w stanach fizjologii i patologii. Warszawa, PZWL. Dermatol Alergol 5: 302.

10. Męcik TJ, Szczurek Z, Cieślik T, Sabat D (2000) Studies on the feasibility of the evaluation of neoplastic tissues calcification in oral tumors; Prace Mineralogiczne 89: 102.
11. Pawlicki M (1995) Rak: nadzieje i rozczarowania Kraków: PAN. Prace Mineralogiczne 84: 23.

12. Pawlikowski M (1987) Mineralizacja organizmu człowieka żyjącego (Mineralogy of human body). Prace Mineralogiczne 79: 12.

13. Pawlikowski M (1991) Mineralizacja nowotworów (Mineralization of cancer). W: A. Szymański Ed. Biomineralizacja i biomateriały. Warszawa PWN 5: 123.

14. Pawlikowski M (1993) Kryształy w organizmie człowiek (Crystals of human body) Kraków, Wydawnictwo i Drukarnia “Secesja”. Prace Mineralogiczne 81: 13.

15. Pawlikowski M (1995) Sekrety mineralizacji tkanek. Kraków(Secrets of tissue mineralization). Wydawnictwo Centrum PPGSMiE PAN. Warszawa PWN 9: 156.

16. Pawlikowski M, Pfitzner R (1999) Mineralizacja serca i dużych naczyń. (Mineralization of heart and big blood vessels). Wyd PAN Kraków 5: 142.

17. Pawlikowski M (2011) Biomineralization of cancer tissues. 20th Int. Symp Molecular and Physiological Aspects of Regulatory Processes of the Organism 8: 190-191.

18. Pawlikowski M (2013) Mineralization of lung cancer tumors. Auxiliary sciences in archaeology ,preservation of relicts and environmental engineering. Minero 15: 125.

19. Pawlikowski M (2014) Osteoporosis as a source of tissue mineralization. Research on osteoporosis therapy and dissolution of arterial mineralization. $J$ Life Sci 8: 610-625.

20. Pawlikowski M (2017) Biomineralogy of angiogenesis. Arch Clin Biomed Res 1: 161-167.

21. Salgia R (1998) Molecular abnormalities in lung cancer. Clinical Oncol 8: 1207 1217.

22. Wołowiec J, Dadej I (2003) Rola UVA w patologii skóry. Postępy Dermatol Alergol 3: $170-175$

23. Woźniak L (2001) Nowotwory: zarys patologii onkologicznej. Postępy Dermatol Alergol 1: 120. 